\title{
Effect of Alkaline Treatment on The Mechanical Properties of Pineapple Leaf Fiber Composite Material
}

\section{Pengaruh Perlakuan Alkali terhadap Sifat Mekanik Material Komposit Serat Daun Nanas}

M Febriyan Baruna Putra ${ }^{1 *}$, Delima Yanti Sari ${ }^{1}$, Hendri Nurdin ${ }^{1}$, Rodesri Mulyadi ${ }^{1}$

\begin{abstract}
Utilization of natural fiber waste, especially pineapple dau fiber, is a major concern and continues to be developed to utilize and optimize plantation waste as a material that is more environmentally friendly, energy efficient and inexpensive. The purpose of this study was to determine the effect of alkaline treatment on the mechanical properties of pineapple leaf fiber composite material as an appropriate alternative material. The method in this research is the experimental method, where the research was carried out by giving variations in the percentage of alkaline $10 \%$ and $20 \%$. The results of the research on the composite material of pineapple leaf fiber using tensile testing showed that giving alkaline treatment with a percentage of $20 \%$ made the fiber stronger but brittle. In addition, the orientation direction and immersion time also affect the tensile strength of the fibers.
\end{abstract}

Keywords

Alkali, Tensile Strenght, Tensile Test, Composite, Pineapple Leaf Fiber

\begin{abstract}
Abstrak
Pemanfaatan limbah serat alam khususnya serat dau nanas menjadi bahan alternatif menjadi perhatian utama serta terus dikembangkan guna memanfaatkan dan mengoptimalkan limbah perkebunan sebagai bahan material yang lebih ramah lingkungan, hemat energi, dan murah. Tujuan penelitian ini untuk mengetahui pengaruh perlakuan alkali terhadap sifat mekanik material komposit serat daun nanas sebagai bahan alternatif tepat guna. Metode dalam penelitian ini yaitu metode eksperimen, dimana penelitian dilakukan dengan pemberian variasi persentase alkali $10 \%$ dan $20 \%$. Hasil penelitian material komposit serat daun nanas dengan menggunakan pengujian tarik menunjukkan bahwa pemberian perlakuan alkali dengan persentase $20 \%$ membuat serat menjadi lebih kuat namun bersifat getas. Selain itu, arah orientasi dan waktu perendaman juga mempengaruhi kekuatan tarik serat.
\end{abstract}

\section{Kata Kunci}

Alkali, Kekuatan Tarik, Uji Tarik, Komposit, Serat Daun Nanas

${ }^{1}$ Pendidikan Teknik Mesin, Universitas Negeri Padang

Fakultas Teknik, Kampus UNP Air Tawar, Jl. Prof. Dr. Hamka, Padang, Sumatera Barat. Kode Pos 25132

*febriyanbaruna16@gmail.com

Submitted : September 04, 2020. Accepted : September 11, 2020. Published : September 15, 2020. 


\section{PENDAHULUAN}

Perkembangan teknologi dibidang industri berkembang dengan pesat beberapa tahun terakhir, dari perkembangan tersebut tentunya kebutuhan akan permintaan material terus meningkat. Hal ini ditandai dengan banyaknya pemakaian material, dimulai dari alat-alat rumah tangga sederhana hingga pada sektor industri skala kecil maupun skala besar. Oleh karena itu material dengan berpenguat serat alam atau material komposit mulai terus dikembangkan dan diteliti lebih lanjut untuk mendapatkan material tepat guna. Pada deklarasi International Year of Natural Fiber 2009 sesuai dengan anjuran FAO (Food and Agriculture Organization) bahwa pemanfaatan serat alam sebagai bahan pembuatan komposit merupakan tindakan yang tepat dalam industri, karena lebih ramah lingkungan serta mudah terdegradasi [1]. Pemanfaatan material komposit sudah mulai dimanfaatkan pada industri otomotif, industri pesawat terbang, industri kapal laut, bukan hanya pada industri saja namun merambah ke bidang lainnya mulai dari alat olahraga hingga, industri elektronik hingga peralatan rumah tangga [2]. Adapun kelebihan material komposit sendiri yakni densitasnya rendah, mudah diuraikan alam, menghasilkan sifat kekakuan yang tinggi, memliki ragam jenis serta hemat energi dan murah [4]. Ada banyak alaternatif yang dapat digunakan sebagai bahan penguat komposit yakni serat bambu, serat tebu, serat pisang, serat ijuk, serat daun nanas dan lain-lain, bahan tersebut tentunya murah dan mudah didapat karena banyak dijumpai di Indonesia [5].

Indonesia sebagai Negara yang memiliki keaneka ragaman hayati yang luas memiliki potensi besar dalam pemanfaatan bahan serat alam sebagai bahan penguat material komposit, salah satunya yakni serat daun nanas. Menurut data Badan Pusat Statistik (BPS), rata-rata produksi nanas di Indonesia adalah 1,5 juta ton/hari. Melihat banyaknya produksi tanaman nanas pertahun, tentunya daun nanas akan berpotensi besar untuk menjadi limbah. Dalam penelitian ini penggunaan serat daun nanas diharapkan dapat menjadi bahan baku alternatif material komposit guna untuk memanfaatkan limbah perkebunan dengan optimal. Daun nanas selain murah dan mudah didapat adapun memiliki keunggulan yakni memiliki gaya tarik dan sifat mekanik antar molekul yang baik serta kandungan selulosa yang tinggi yakni 70-82\% [6][7].

Meskipun banyak kelebihan yang didapat dari material berpenguat serat alam tidak menutup kemungkinan adanya kelemahan, kelemahan dari serat alam sendiri yakni mudah menyerap air (hidrofil) yang dapat menurunkan sifat mekanik dan perbedaan polaritas antara serat alam dengan matrik yang digunakan. Adapun upaya untuk mengatasi kelemahan tersebut salah satunya yakni dengan cara melakukan pemberian perlakuan kimia ( $\mathrm{NaOH})$ [8]. Namun selain diberikan perlakuan kimia $(\mathrm{NaOH})$ ada faktor lain yang juga mempengaruhi sifat mekanik komposit yakni arah orientasi serat [9]. Sejauh ini masih belum banyak diketahui seberapa besar pengaruh dari pemberian perlakuan alkali serta orientasi arah serat terhadap sifat mekanik khususnya pada serat daun nanas.

Pengujian tarik merupakan salah satu pengujian yang dilakukan untuk mengetahui sifat mekanik dari suatu material. Dari pengujian tarik yang dilakukan akan terjadi patahan, patahan akibat beban tarik yang diberikan terjadi akibat adanya tegangan. Proses terjadinya patah (gagal) diawali dari retak yang berlanjut ke penjalaran retak (crack propogation)[10]. Adapun prinsip kerja dari pengujian tarik yakni dengan melakukan pemberian pembebanan statis secara bertahap hingga spesimen putus, untuk standar spesimen uji tarik yang digunakan yakni ASTM D638-03 [11]. Selama pemberian pembebanan mesin merekam pertambahan beban serta perpanjangan spesimen dalam bentuk grafik tegangan dan regangan. Sifat mekanik yang diperoleh dari hasil pengujian tarik yakni tegangan tarik, regangan dan modulus elastisitas. 
Priyandokohadi S. dan C. Riezki [12] meneliti terkait dengan arah orientasi serat $0^{0}$ pada serat agave dan serat sansivera menyimpulkan bahwa kekuatan tarik yang didapat dari komposit berpenguat serat agave yakni sebesar 64,79 MPa sedangkan serat sansivera yakni sebesar 62,03 MPa. Selanjutnya penelitian yang dilakukan Dita Novi Susanti [13] dalam penelitiannya menggunakan serat daun nanas dengan persentase alkali 30\% waktu perendaman 2 jam, hasil kekuatan tarik yang didapat yakni sebesar $25,17 \mathrm{MPa}$. Dalam penelitian ini pemberian alkali $(\mathrm{NaOH})$ yang diteliti yakni 10\% dan 20\% lama waktu perendaman 1 jam, 2 jam, dan 3 jam dengan arah orientasi serat $0^{\circ}, 30^{\circ}$, dan $60^{\circ}$. Penelitian ini bertujuan untuk mengetahui kekatan tarik yang didapat setelah dilakukan pemberian perlakuan alkali serta arah orientasi serat daun nanas. Dengan dilakukannya penelitian ini diharapkan nantinya serat daun nanas dapat digunakan sebagai bahan baku alternatif dengan memanfaatkan potensi kekayaan alam Indonesia, selain murah dan mudah didapat juga untuk mengetahui seberapa besar pengaruh kimia yang diberikan.

\section{METODE PENELITIAN}

Metode penelitian yang digunakan yakni penelitian eksperimen (experimental research), penelitian dilakukan langsung pada benda uji atau spesimen, dimulai dari menyiapkan alat dan bahan, mengerjakan spesimen uji hingga melakukan pengujian langsung. Data yang didapat dari hasil pengujian langsung kemudian dilanjutkan pengamatan serta analisa.

\section{Alat dan Bahan}

Alat yang digunakan dalam penelitian ini yakni mesin uji tarik Monsanto Tensometer Education Kit dengan kapasitas pembenan tarik 500 kN sampai maksimum $1000 \mathrm{kN}$. Bahan yang digunakan yakni material komposit polimer, adapun matriksnya yakni resin polyester tak jenuh BQTN 157-EX, dan untuk penguatnya serat daun nanas.

\section{Prosedur Penelitian}

Serat daun nanas didapat dari industry rumahan ALFIBER subang Jawa Barat. Langkah awal pembuatan spesimen uji diawali dengan pelarutan butiran alkali $(\mathrm{NaOH})$ didalam aquades, setelah cairan alkali $(\mathrm{NaOH})$ didapat serat daun nanas direndam dalam cairan tersebut dengan dengan persentase $10 \%$ dan 20\% dengan lama waktu perendaman 1 jam, 2 jam, dan 3 jam. Setelah dilakukan perlakuan alkali, serat dicuci hingga bersih menggunakan air mengalir dan kemudian dijemur hingga kering. Komposit dibuat dengan menggunakan metode pembuatan hand lay - up dengan perbandingan resin dan serat 70:30 dan katalis 1\% dari resin. Pengujian tarik dilakukan untuk mendapatkan hasil yakni tengangan, regangan dan modulus elastistas.

\section{Teknik Analisis Data}

Penelitian ini menggunakan metode statistika deksriptif untuk menganalisis data teknik pengumpulan data berupa informasi atau data dari hasil eksperimen secara langsung. Data tersebut nantinya ditabulasikan dari hasil pengujian dari masing-masing spesimen untuk mendapatkan sifat mekanis material komposit polimer berpenguat serat daun nanas.

Dalam melakukan pengujian khususnya pada pengujian tarik untuk mengetahui sifat mekanik pada pada spesimen uji dapat dilakakukan perhiutngan secara teoritis [14]. Rumus yang digunakan dalam penelitian ini adalah:

Menghitung Tengangan tarik $(\sigma)$ :

$\begin{array}{ll}\sigma & =\frac{P}{\mathrm{~A}} \quad \ldots \ldots \ldots \ldots \ldots \ldots \ldots \ldots \ldots \ldots \ldots \ldots \\ \text { Keterangan: } & \sigma=\text { Tegangan tarik }(\mathrm{MPa}) \\ & \mathrm{P}=\text { Gaya }(\mathrm{N}) \\ \mathrm{A} & =\text { Luas penampang spesimen }\left(\mathrm{mm}^{2}\right)\end{array}$


Menghitung Regangan $(\varepsilon)$ :

$$
\begin{aligned}
\varepsilon & =\frac{\Delta L}{L}=\frac{l_{i}-l_{O}}{L} \ldots \ldots \ldots \ldots \ldots \ldots \ldots \ldots \ldots \ldots \ldots \ldots \\
\text { Keterangan: } \quad \ldots & =\text { Regangan }(\%) \\
\mathrm{L} & =\text { Panjang Spesimen }(\mathrm{mm}) \\
\Delta \mathrm{L} & =\text { Pertambahan panjang akibat beban tarik }(\mathrm{mm}) \\
l_{o} & =\text { Panjang awal }(\mathrm{mm}) \\
l_{i} & =\text { Panjang setelah pengujian tarik }(\mathrm{mm})
\end{aligned}
$$

Menghitung Modulus Elastisitas:

$$
\sigma=E . \varepsilon
$$

$$
\begin{array}{ll}
\text { Keterangan: } & \mathrm{E}=\text { Modulus Elastisitas }(\mathrm{GPa}) \\
\sigma & =\text { Tegangan tarik }(\mathrm{MPa}) \\
\varepsilon & =\text { Regangan }(\%)
\end{array}
$$

Material komposit merupakan campuran antara resin sebagai matriks dan serat sebagai penguat, untuk mendapatkan karakteristik komposit anatara resin dan serat dapat dilakukan perhitungan secara teoritis[15].

Menghitung karakteristik komposit:

$$
\begin{aligned}
& \rho_{c}=\rho_{m} \cdot V_{m}+\rho_{f} \cdot \rho_{f} \ldots \ldots \ldots \ldots \ldots \ldots \ldots \\
\text { Keterangan: } \quad \rho_{c} & =\text { Densitas Komposit } \\
& \rho_{m}=\text { Massa jenis matrik } \\
V_{m} & =\text { Fraksi Volume matrik } \\
\rho_{f} & =\text { Massa jenis matrik } \\
V_{f} & =\text { fraksi Volume matrik }
\end{aligned}
$$

Dalam menentukan ketebalan material komposit dengan fraksi volume resin dan serat yang dikandung oleh komposit, yang menunjukkan jumlah fraksi beratnya. Dapat diperoleh dengan melakukan perhitungan secara teoritis[15].

Menghitung fraksi volume resin dan serat:

$$
W=\frac{V_{m} \cdot \rho_{m}}{V_{m} \cdot \rho_{m}+V_{f} \cdot \rho_{f}} \ldots \ldots \ldots \ldots \ldots \ldots \ldots 5
$$

Keterangan: $\quad \mathrm{W}=$ Massa total Komposit $(\mathrm{kg})$

$$
\begin{aligned}
& \mathrm{V}_{\mathrm{m}}=\text { fraksi Volume matrik }\left(\mathrm{m}^{3}\right) \\
& \rho_{\mathrm{m}}=\text { Massa jenis matrik }\left(\mathrm{kg} / \mathrm{m}^{3}\right) \\
& \mathrm{V}_{\mathrm{f}}=\text { Volume serat }\left(\mathrm{m}^{3}\right) \\
& \rho_{\mathrm{f}}=\text { Massa jenis serat }\left(\mathrm{kg} / \mathrm{m}^{3}\right)
\end{aligned}
$$

\section{HASIL DAN PEMBAHASAN}

Hasil pengujian tarik material komposit berpenguat serat daun nanas perbandingan 70:30, dengan persentase alkali 10\% dan 20\% dengan lama waktu perendaman 1 jam, 2 jam, dan 3 jam serta arah orientasi sudut $0^{\circ}, 30^{\circ}$, dan $60^{\circ}$ dengan metode pembuatan hand lay - up untuk melihat sifat mekanis tegangan tarik, regangan, dan modulus elastisitas. Spesimen uji dapat dilhat pada Gambar 1. 


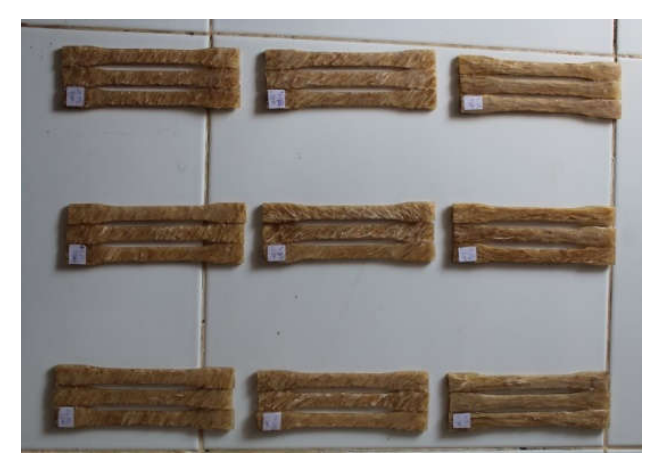

Gambar1. Spesimen Uji Serat Daun Nanas

Tabel 1. Material Komposit Serat Daun Nanas Perlakuan Alkali (10\% NaOh).

\begin{tabular}{|c|c|c|c|c|c|}
\hline \multicolumn{2}{|c|}{ Komposit } & \multirow[b]{2}{*}{ Arah Orientasi Serat } & \multirow[b]{2}{*}{ Tegangan } & \multirow[b]{2}{*}{ Regangan } & \multirow{2}{*}{$\begin{array}{l}\text { Modulus } \\
\text { Elastisitas }\end{array}$} \\
\hline $\begin{array}{c}\text { Resin } \\
70 \%\end{array}$ & $\begin{array}{l}\text { Serat } \\
30 \%\end{array}$ & & & & \\
\hline \multirow{3}{*}{\multicolumn{2}{|c|}{ Tanpa Perlakuan }} & $0^{0}$ & 49,6 & 1,61 & 3,2 \\
\hline & & $30^{0}$ & 38,1 & 0,94 & 4,12 \\
\hline & & $60^{0}$ & 28,3 & 0,66 & 3,15 \\
\hline \multirow{3}{*}{\multicolumn{2}{|c|}{1 jam }} & $0^{0}$ & 30,4 & 0,62 & 4,96 \\
\hline & & $30^{0}$ & 12,9 & 0,67 & 1,92 \\
\hline & & $60^{0}$ & 17,0 & 0,50 & 3,44 \\
\hline \multirow{3}{*}{\multicolumn{2}{|c|}{2 jam }} & $0^{0}$ & 26,7 & 0,46 & 5,87 \\
\hline & & $30^{0}$ & 21,1 & 0,68 & 3,14 \\
\hline & & $60^{0}$ & 12,4 & 0,35 & 3,89 \\
\hline \multirow{3}{*}{\multicolumn{2}{|c|}{3 jam }} & $0^{0}$ & 29,0 & 0,63 & 4,68 \\
\hline & & $30^{0}$ & 16,8 & 0,65 & 2,67 \\
\hline & & $60^{0}$ & 11,4 & 0,29 & 2,97 \\
\hline
\end{tabular}

Tabel 2. Material Komposit Serat Daun Nanas Perlakuan Alkali (20\% NaOh).

\begin{tabular}{|c|c|c|c|c|c|}
\hline \multicolumn{2}{|c|}{ Perlakuan Alkali } & \multirow[b]{2}{*}{ Arah Orientasi Serat } & \multirow[b]{2}{*}{ Tegangan } & \multirow[b]{2}{*}{ Regangan } & \multirow{2}{*}{$\begin{array}{c}\text { Modulus } \\
\text { Elastisitas }\end{array}$} \\
\hline $\begin{array}{c}\text { Resin } \\
70 \%\end{array}$ & $\begin{array}{c}\text { Serat } \\
30 \%\end{array}$ & & & & \\
\hline \multirow{3}{*}{\multicolumn{2}{|c|}{ Tanpa Perlakuan }} & $0^{0}$ & 49,6 & 1,61 & 3,22 \\
\hline & & $30^{0}$ & 38,1 & 0,94 & 4,12 \\
\hline & & $60^{0}$ & 28,3 & 0,66 & 3,15 \\
\hline \multirow{3}{*}{\multicolumn{2}{|c|}{1 jam }} & $0^{0}$ & 31,6 & 0,59 & 5,33 \\
\hline & & $30^{0}$ & 29,1 & 0,60 & 4,86 \\
\hline & & $60^{0}$ & 21,9 & 0,47 & 4,55 \\
\hline \multirow{3}{*}{\multicolumn{2}{|c|}{2 jam }} & $0^{0}$ & 41,4 & 0,51 & 6,20 \\
\hline & & $30^{0}$ & 24,0 & 0,67 & 3,60 \\
\hline & & $60^{0}$ & 22,0 & 0,48 & 4,54 \\
\hline \multirow{3}{*}{\multicolumn{2}{|c|}{3 jam }} & $0^{0}$ & 42,9 & 0,84 & 5,32 \\
\hline & & $30^{0}$ & 27,9 & 0,80 & 3,49 \\
\hline & & $60^{0}$ & 18,2 & 0,44 & 4,09 \\
\hline
\end{tabular}

Berdasarkan hasil penelitian pengujian tarik di Labor Material dan Metrologi Fakultas Teknik Universitas Negeri Padang dengan menggunakan alat mesin uji tarik Monsanto Tensometer Education Kit dan telah dilakukan analisa, maka diperoleh data yang 
diilustrasikan berupa tabel dan grafik. Adapun sifat mekanis yang didapat dari hasil rata-rata beberapa spesimen yang diujikan dapat dilihat pada Tabel 1 dan 2.

Dapat dilihat sifat mekanis dari hasil pengujian tarik komposit berpenguat serat daun nanas dengan menggunakan mesin uji tarik Monsanto Tensometer Education Kit, yakni hasil tegangan tarik tertinggi yaitu pada arah orientasi serat $0^{0}$ dengan perlakuan alkali $\mathrm{NaOH} 20 \%$ selama 3 jam perendaman yaitu 42,9 MPa dapat dilihat pada Gambar 2, sedangkan hasil yang terendah adalah pada komposit serat daun nanas pada arah orientasi serat $60^{\circ}$ dengan perlakuan alkali $\mathrm{NaOH} 10 \%$ sebesar 11,4 MPa dapat dilihat pada Gambar 2.

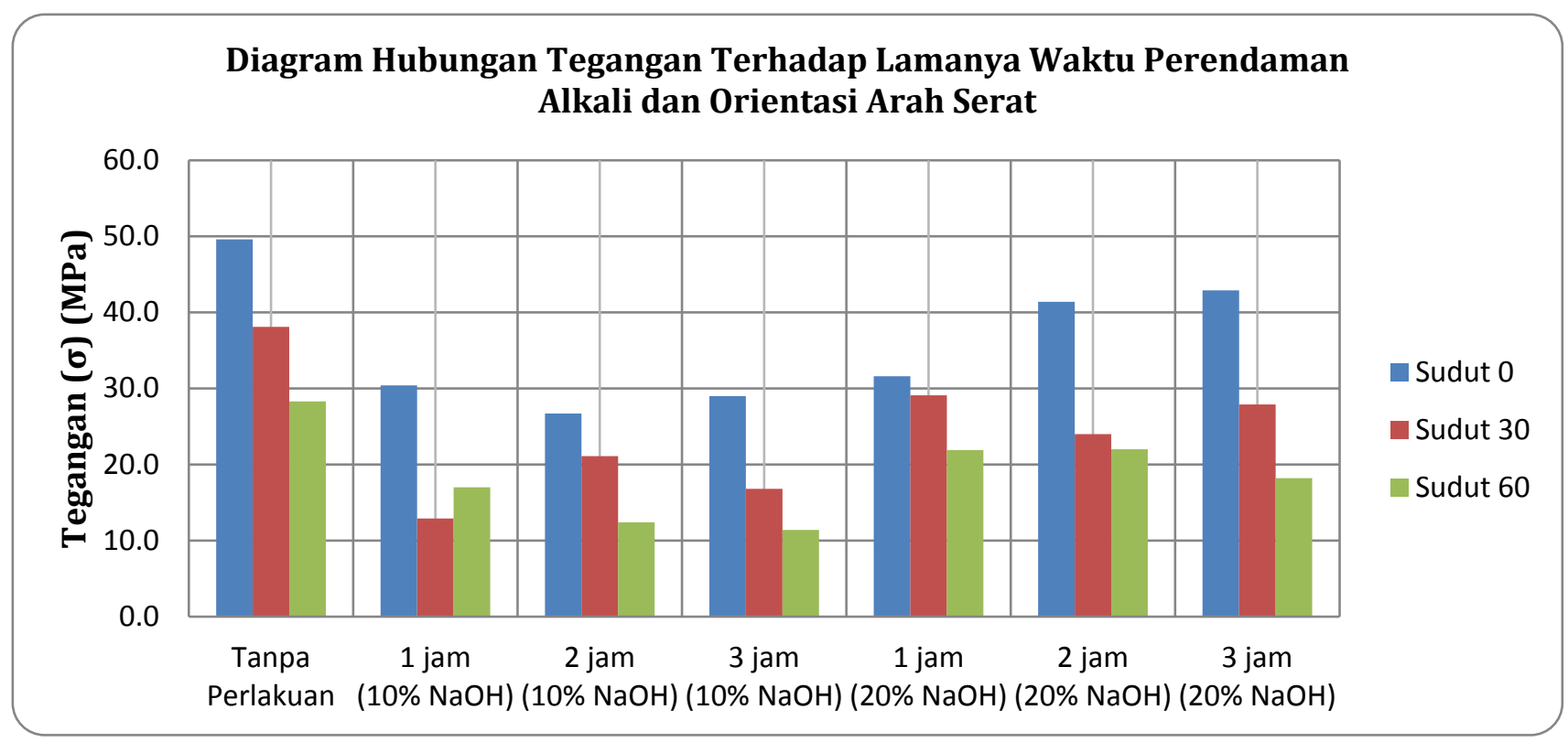

Gambar 2. Grafik Hubungan Tegangan Terhadap Lama Waktu Perendaman Alkali dan Orientasi Arah Serat

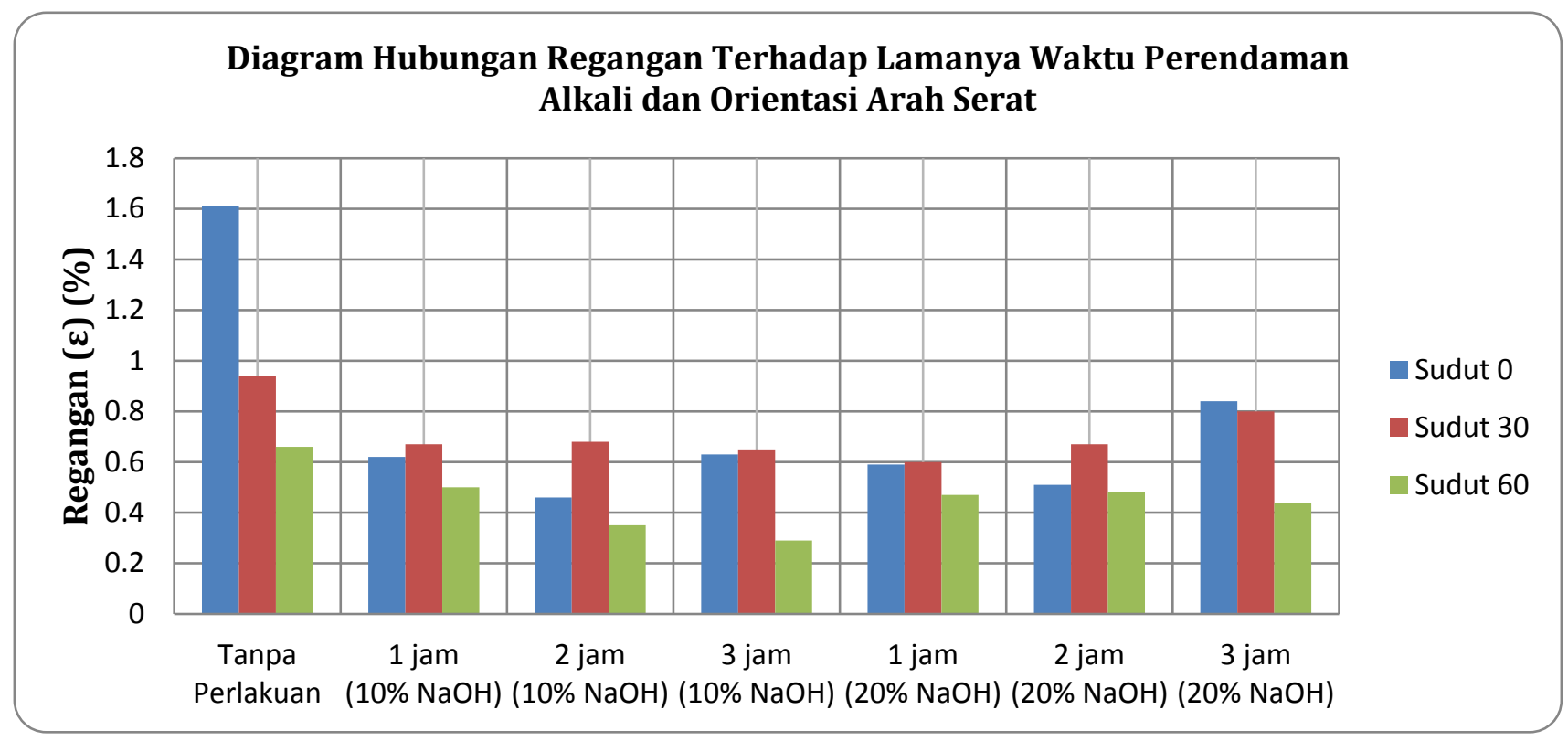

Gambar 3. Grafik Hubungan Regangan Terhadap Lama Waktu Perendaman Alkali dan Orientasi Arah Serat

Pembuatan material komposit serat alam, selain perendaman alkali $(\mathrm{NaOH})$, faktor lain yang juga mempengaruhi sifat mekanik komposit adalah arah orientasi serat [9]. Dari hasil 
penelitian dapat diketahui bahwa orientasi arah serat mempengaruhi sifat mekanis material komposit berpenguat serat daun nanas khususnya pada arah orientasi serat $0^{0}$ dengan perlakuan alkali $\mathrm{NaOH} 20 \%$ memliki kekuatan tarik tertinggi dibandingkan dengan serat dengan arah orientasi $60^{\circ}$ dengan perlakuan alkali $\mathrm{NaOH} 10 \%$. Namun setelah diberikan pemberian alkalisasi dan lama waktu perendaman yang telah ditentukan sebelumnya kekuatan tarik serat daun nanas sedikit menurun dari serat tanpa diberikan perlakuan alkali ini menandakan bahwa serat yang diberikan perlakuan alkali menjadi lebih kuat namun bersifat getas dan mudah patah. Pemberian persentase perlakuan alkali pada serat serta lama waktu perendaman yang tidak tepat dapat menyebabkan kerusakan pada unsur selulosa sehingga serat menjadi rapuh dan mudah putus[16].

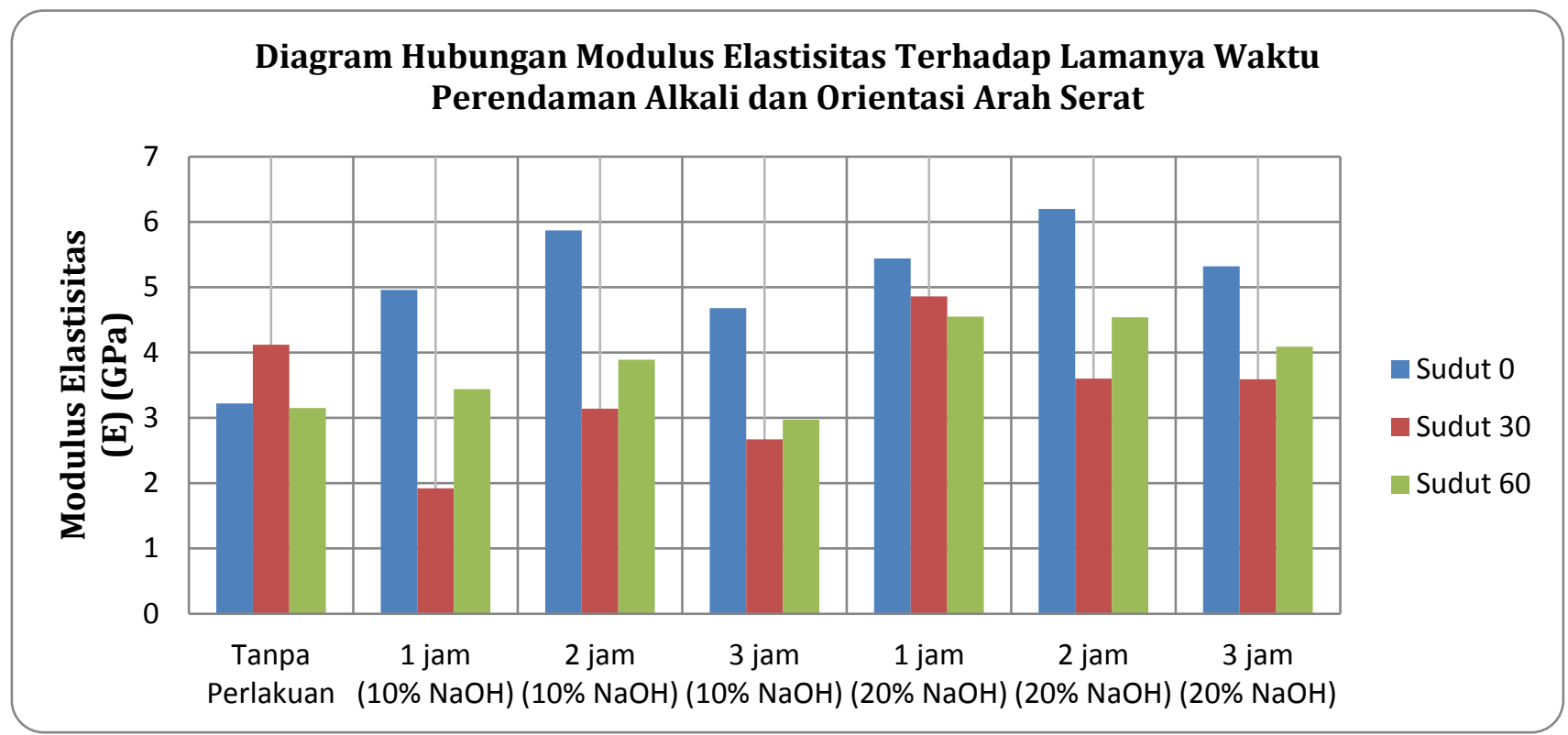

Gambar 4. Grafik Modulus Elastisitas Terhadap Lama Waktu Perendaman Alkali dan Orientasi Arah Serat

Dapat diketahui bahwa pada data hasil pengujian tarik menunjukkan bahwa modulus elastisitas komposit berpenguat serat daun nanas mengalami peningkatan terutama pada komposit arah orientasi serat $0^{0}$ dan $60^{\circ}$ dengan waktu perendaman 1 dan 2 jam dapat dilihat pada Gambar 4, dari peningkatan tersebut menandakan bahwa semakin sulit suatu benda tersebut bertambah panjang atau tahan terhadap perubahan bentuk [17]. Lama waktu perendaman alkalisasi terentu yang diberikan pada serat, nantinya akan mengalami peningkatan pada modulus elastisitnya [8]. Dari hasil data pengujian yang didapat bahwa serat daun nanas setelah diberikan perlakuan alkali dengan persentase dan waktu perendaman tertentu mempengaruhi tegagan tarik pada serat, sehingga semakin kecil nilai regangan yang didapat dan meningkatnya modulus elastisitas.

\section{SIMPULAN DAN SARAN}

\section{Simpulan}

Hasil penelitian serat daun nanas terhadap kekuatan tarik menunjukkan bahwa perlakuan alkali dengan persentase $20 \%$, arah orientasi $0^{0}$ dengan waktu perendaman 3 jam menghasilkan kekuatan tarik lebih tinggi dibandingkan persentase $10 \%$, arah orientasi dan waktu perendaman lainnya. Dapat disimpulkan bahwa setelah diberikan perlakuan alkali $(\mathrm{NaOH})$ menunjukkan bahwa serat daun nanas menjadi lebih kuat namun bersifat getas, 
dilihat dari kecil nilai regangan yang didapat pada serat daun nanas setelah diberikan perlakuan serta terjadinya peningkatan pada nilai modulus elastisitas.

\section{Saran}

Penelitian selanjutnya diharapakan agar dalam proses pembuatan material komposit memperhatikan saat pengadukan matriks yakni resin dan katalis agar tidak adanya void atau gelembung udara, karena jika terdapat gelembung udara pada material komposit nantinya dapat mempengaruhi sifat mekanis dari hasil pengujian yang didapat.

\section{DAFTAR RUJUKAN}

[1] X. Salahudin, P. Studi, T. Mesin, F. Teknik, and U. Tidar, "Kaji Pengembangan Serat Daun Pandan di Kabupaten Magelang Sebagai Bahan Komposit Interior Mobil," pp. 1-13, 2012.

[2] K. Anam, A. Purnowidodo, and A. O. Yudhanto, "Pengaruh Variasi Fraksi Volume Serat Daun Nanas dan Ukuran Cetakan terhadap Prosentase Penyusutan Komposit Matriks Polyester dengan Cetakan Silikon," no. Snttm Xiv, pp. 7-8, 2015.

[3] A. K. Mohanty, M. Misra, and L. T. Drzal, Natural fibers, biopolymers, and biocomposites. 2005.

[4] J. Rowell, "Chapter 5. Paper and Composites from Agro-based Resources," in Chemical Composition of Fibers",1997.

[5] T. S. Hadi, S. Jokosisworo, and P. Manik, "Analisa Teknis Penggunaan Serat Daun Nanas Sebagai Alternatif Bahan Komposit Pembuatan Kulit Kapal Ditinjau Dari Kekuatan Tarik, Bending Dan Impact," J. Tek. Perkapalan, vol. 4, no. 1, pp. 323-331, 2016.

[6] A. Danladi and J. Shu'aib, "Fabrication and Properties of Pineapple Fibre / High Density Polyethylene Composites," Am. J. Mater. Sci., vol. 2014, no. 3, pp. 139-143, 2014.

[7] S. Sapuan 1,2,b and S. Izwan 1a, "Mechanical Properties (Impact Strength) of Pineapple Leaf Fibre Reinforced Polypropylene Composites With Variation of Fibre Loading and Treatment Process.," Mater. Sci. Adv. Compos. Mater., vol. 2, no. 4, pp. 1-16, 2018.

[8] K. Diharjo, "Pengaruh Perlakuan Alkali terhadap Sifat Tarik Bahan Komposit," Jur. Tek. Mesin Vol. 8, No. 1, April 20068 - 13, vol. 8, pp. 8-13, 2006.

[9] H. Fahmi and H. Hermansyah, "Pengaruh Orientasi Serat Pada Komposit Resin Polyester/ Serat Daun Nenas Terhadap Kekuatan Tarik,” Tek. Mesin Undana, vol. 1, no. 1, pp. 46-52, 2011.

[10] N. Hendri, Mulianti, "Pengaruh Bentuk Takikan (NOTCHED) pada Poros Baja Karbon ST.60 Akibat Beban Tarik", Vol. 8, no. 1, pp. 50-54, 2011.

[11] J. Oliver, Principal of composite mechanics, vol. 53, no. 9. 2013.

[12] S. Priyandokohadi and C. A. Rizeki, "Analisa Pengaruh Orientasi Arah Serat terhadap Kekuatan Tarik dan Impact Material Komposit Serat Alam (Serat Agave dan Serat Sansivera)," Tek. Mesin, vol. 4, no. 1, 2018.

[13] Dita Novi Susanti. "Pengaruh Variasi Panjang Serat Nanas terhadap Kekuatan Tarik Dan Impact Komposit Polyester - Serat Nanas". pp. 1-10, 2018.

[14] S.Timoshenko. "Strength_Of_Materials_parts_IandII-Timoshenko.pdf." p. 510. 1940

[15] Hwerakovich, C.T. Mechanical of Fibrous Composities, John Wiley Sons. Inc: first Edition, USA. 1998.

[16] Nurfajri dan Arwizet K. “Analisis Kekuatan Tarik Komposit Serabut Kelapa Dan Ijuk Dengan Perlakuan Alkali (Naoh)”. Ranah Research. Hlm. 791-797. 2019.

[17] Kiswadi. Kekuatan Tarik Komposit Lamina Berbasis Anyaman Serat Karung Plastik Bekas (Woven Bag). Skripsi. Jurusan Teknik Mesin Fakultas Teknik Universitas Negeri Semarang. 2017. 